\title{
Flexibility in the Mathematics Major Would Benefit Students and Society
}

\section{by William Yslas Vélez}

\section{Note: The opinions expressed here are not necessarily those of Notices.}

Responses on the Notices webpage are invited.

Mathematics and engineering have been undergraduate majors at US universities since the early 1900s. To meet the technological changes that occurred in the last hundred years, the career paths of engineers and mathematicians changed, and engineering has expanded by adding several specialties. In 1950 the College of Engineering at the University of Arizona (UA) had three degree programs: mechanical, civil, and electrical. Now at the UA

there are 14 different engineering programs, including Engineering Management, which prepares engineers to run a business, become entrepreneurs, and launch their own high-tech firms. Why aren't we all providing mathematics majors the option for exactly this kind of training?

What happened to the mathematics major over this same time period? In 1950, at the UA (similarly at San Diego State (SDSU) and the University of California, Los Angeles (UCLA)) the mathematics major

William Yslas Vélez is professor of mathematics at the University of Arizona. His e-mail address is velez@math . arizona.edu

For permission to reprint this article, please contact:

reprint-permission@ams . org.

DOI: http://dx.doi.org/10.1090/noti1574

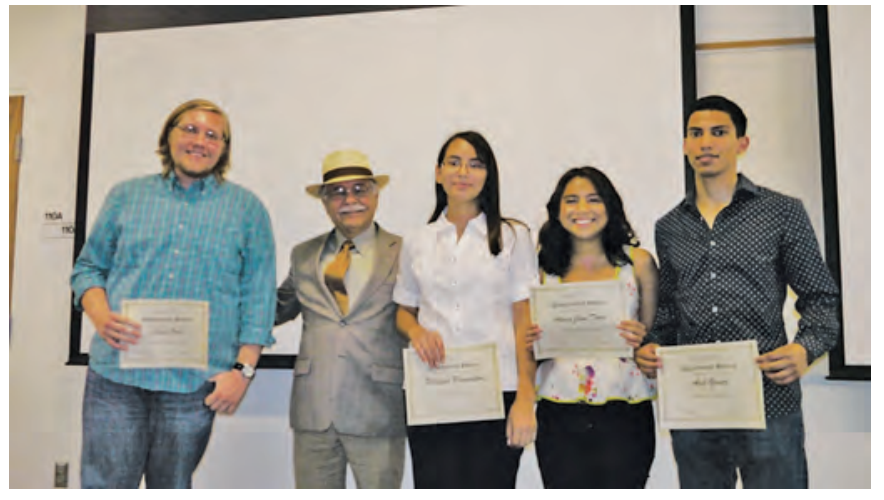

Vélez with four math majors: Craig Gross, Philippa Pinnington, Alexis Jane Torre, and Axel Gomez Casarez.

consisted of 24 units, with 12 of those having to be upper division. Neither abstract algebra nor linear algebra was offered at the undergraduate level at the UA or SDSU. By 1965 the programs of study had morphed into programs we would all recognize. The number of required units went to the mid 30s and the core program of study required analysis (convergence and continuity using $\varepsilon \delta$ ), abstract algebra, linear algebra, complex variables, and perhaps topology.

What changed in the mathematics program of study in the 50 years since 1965 ? For many departments, the requirement for the mathematics degree is the same core that was in place 50 years ago. Are we preparing undergraduate mathematics majors as classicists or as mathematical scientists, prepared to address today's 
problems with analytical thinking applied with modern technological tools?

A common view among mathematicians is that there are two standard paths for mathematics majors, becoming a high school mathematics teacher or pursuing graduate studies in mathematics. A recent Notices report [1] provides an estimate of 15 percent for the percentage of mathematics majors who pursue graduate studies in the mathematical sciences (mathematics, applied mathematics, statistics, and biostatistics). It would be difficult to call undergraduate programs successful if their vision is for their graduates to pursue graduate training in the mathematical sciences and this percentage is around 15 percent. Given that statistics and biostatistics and many graduate programs in applied mathematics do not require abstract algebra, it is possible that the percentage of mathematics majors who pursue graduate programs in pure mathematics is less than five percent. How can we offer a program of study for five percent of our undergraduate majors and make all the other mathematics majors go through this program? Worse, this view of mathematical training completely dominates our upper-division courses, which other majors may not find germane.

We should be preparing students to use their mathematical training to pursue challenges in business, science, and industry. Instead of abstract algebra and analysis, these students would benefit from differential equations, probability and statistics, data analysis, and computational mathematics. Fortunately, we do have evidence of change. The departments that I mentioned above have created options that are more flexible, that allow students to graduate as mathematics majors without courses in abstract algebra and analysis. The University of California, Merced has gone even further. Its department is called Applied Mathematics, not Mathematics. They do not offer year-long courses in abstract algebra or analysis.

Here might be the crux of the matter. Should students who do not study abstract algebra and analysis be called mathematics majors? Perhaps it is the name of the major that is the problem! The name conjures up the training that faculty had for graduate school. If we renamed the undergraduate major or accepted that the undergraduate major would not lead necessarily to graduate school in the mathematical sciences, then a department might be more willing to accept that mathematical training should be different from what it was 50 years ago. There are a growing number of departments that are doing just this.

Mathematics departments with a small number of faculty may not have the resources to offer different options to students, so they select the standard path, abstract algebra and analysis. For those programs I would ask: How many of your students pursue graduate programs in pure mathematics? How many non-majors take your upper-division mathematics courses? Might your students be better served by offering a program of study that prepares them for a broader array of careers?
Of course, a non-traditional program of study does have a drawback: mathematical talent or interest can appear late in a student's undergraduate career making it impossible to take those courses preparatory for graduate studies in the mathematical sciences. We need to address this. There are currently a few post-bac programs whose function is exactly this: to help students transition from a BS degree that did not provide them with the material necessary to pursue graduate programs in the mathematical sciences. In fact, these post-bac programs are models of what could be a much more effective program for the mathematical sciences. Undergraduate programs could provide a different and broader undergraduate curriculum, thereby increasing the mathematical preparation of more students, and for those students who find an increased interest in mathematics, a one-year post-bac program could then provide preparation for graduate school.

\section{References}

[1] ThOmas H. BARR, JAMES W. MAXWELl, and William YSlaS VÉLEZ, Recent Trends in Bachelors Degree Recipients in Mathematics at US Institutions, Notices Amer. Math. Soc. 63 (June/ July, 2016), 660-665.

\section{Photo Credits}

The photo of Velez and the math majors is courtesy of the University of Arizona Math Department.

The author headshot is courtesy of William Yslas Vélez.

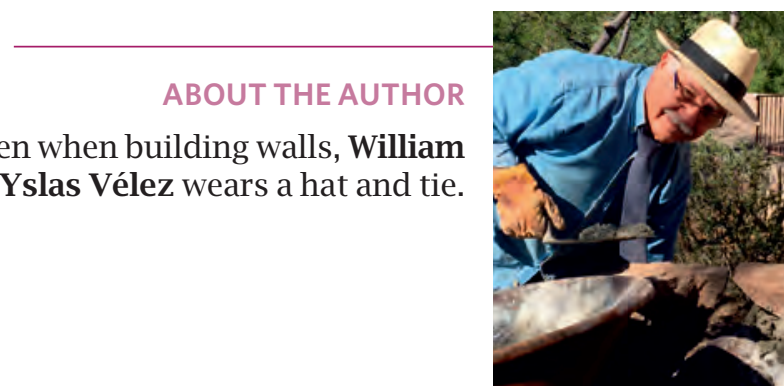

William Yslas Vélez 